\title{
Phosphorus Use Efficiency as Influenced by NP Ratios to Pigeonpea and Fertilizer Levels to Intercrop in Pigeonpea + Blackgram System
}

\author{
Deepa Kempagoudra and Ganajaxi Math* \\ Department of Agronomy, College of Agriculture, Dharwad, University of Agricultural \\ Sciences, Dharwad-580 005, Karnataka, India \\ *Corresponding author
}

\section{A B S T R A C T}

\section{Keywords}

Fertilizer levels, NP ratios, PEY

(pigeonpea

equivalent yield),

Net returns, PUE

(phosphorus use

efficiency)

\section{Article Info}

Accepted:

07 October 2020

Available Online:

10 November 2020

\begin{abstract}
The field experiment included nine treatment combinations with two fertilizer levels to intercrop as main plot $\left(\mathrm{F}_{1}-50 \%\right.$ and $\mathrm{F}_{2}-100 \% \mathrm{RDF}$ to intercrop) and four N:P ratios to pigeonpea as sub plots $\left[\mathrm{L}_{1}-1: 2\left(25: 50 \mathrm{~kg} \mathrm{~N}: \mathrm{P}_{2} \mathrm{O}_{5} \mathrm{ha}^{-1}\right), \mathrm{L}_{2}-1: 2.5\left(25: 62.5 \mathrm{~kg} \mathrm{~N}: \mathrm{P}_{2} \mathrm{O}_{5}\right.\right.$ $\left.\mathrm{ha}^{-1}\right), \mathrm{L}_{3}-1: 3\left(25: 75 \mathrm{~kg} \mathrm{~N}: \mathrm{P}_{2} \mathrm{O}_{5} \mathrm{ha}^{-1}\right)$ and $\left.\mathrm{L}_{4}-1: 3.5\left(25: 87.5 \mathrm{~kg} \mathrm{~N}: \mathrm{P}_{2} \mathrm{O}_{5} \mathrm{ha}^{-1}\right)\right]$ and one absolute control (without any fertilizer application to both the crops). Non- significant difference was noticed in nutrient status of soil with respect to different fertilizer levels to intercrop. Among the N:P ratios to pigeonpea, 1:3, 1:3.5 recorded significantly higher available nitrogen, phosphorus and organic carbon $(239.72,241.60$ and 45.35, 47.50 $\mathrm{kg} \mathrm{ha}^{-1}$ and $0.49,0.50 \%$, respectively). Among the interactions, available nitrogen, phosphorus and organic carbon in soil was found significantly higher with $100 \%$ RDF to intercrop with $\mathrm{N}: \mathrm{P}$ ratio of $1: 3.5\left(243.20,49.14 \mathrm{~kg} \mathrm{ha}^{-1}\right.$ and $0.52 \%$, respectively). Agronomic efficiency was found significantly higher with 50 and $100 \%$ RDF to intercrop with N:P ratio of 1:3 and 1:3.5 (7.50,7.57 and 7.93, 7.63, respectively) of the system. Among the interactions, $\mathrm{F}_{2} \mathrm{~L}_{3}, \mathrm{~F}_{2} \mathrm{~L}_{4}$ showed significantly higher PEY, gross and net returns $\left(2537,2597 \mathrm{~kg} \mathrm{ha}^{-1}\right.$, ₹ $1,43,971,1,47,390 \mathrm{ha}^{-1}$, and ₹ $1,02,771,1,05,566 \mathrm{ha}^{-1}$, respectively) over others except $\mathrm{F}_{1} \mathrm{~L}_{3}, \mathrm{~F}_{1} \mathrm{~L}_{4}$ and indicated that $50 \% \mathrm{RDF}$ was enough to intercrop when main crop was supplied with 75 and $100 \mathrm{~kg} \mathrm{P}_{2} \mathrm{O}_{5}$.
\end{abstract}

\section{Introduction}

India is the largest producer, consumer and importer of pulses in the world. In the present scenario, because of tremendous increase in population there is decrease in per capita availability of land. So there is need to maximise productivity per unit area. One of the best approaches to increase production potential and profitability per unit land area is intercropping system (Nagar et al., 2015).
Since pulses are rich sources of proteins, for majority of vegetarians they aid in building of tissues. So they are regarded as backbone of nutritional security of our country. Among different intercropping systems the legume based intercropping system provides advantages like roots increase the solubility of phosphorus in the rhizosphere by release of some organic acids like picidic, citric, maleic acids, addition supply nitrogen to component crop and increase in population of beneficial 
microorganisms that maintains proper soil health and provides a synergistic effect.

Pigeonpea (Cajanus cajan L. Millsp) is the second most important pulse crop after chickpea with protein content of $22 \%$ that makes an excellent source of protein supplement to vegetarian population. In India it is being cultivated on an area of 5.33 million hectare, with a production of 4.87 million tonnes and productivity of $913 \mathrm{~kg} \mathrm{ha}^{-1}$ (Anon., 2018). Wider row spacing of pigeonpea offers scope to grow intercrops in between the rows to improve productivity. Other special features include drought tolerance, withstanding capacity of harsh climate, biological nitrogen fixation etc...

Blackgram (Vigna mungo L.) is short duration legume crop grown on an area of 4.47 million hectare, with a production of 2.83 million tonnes and productivity of $632 \mathrm{~kg} \mathrm{ha}^{-1}$ (Anon., 2018a). It fetches higher price because of its high nutritional value.

Pulse production has many constraints that include poor nutrient management. Macro nutrients like nitrogen, phosphorus have a vital role in pulse productivity. Nitrogen is building block of plant proteins, constituent of chlorophyll that keeps plant tissues green with vigorous growth.

Phosphorus is the most limiting nutrient for legumes. It assists in root development, nodulation, photosynthesis and respiration. Being a constituent of adenosine tri phosphate (ATP) it is involved in an energy transfer in various biochemical reactions, cell division and development of new tissues.

An essential index that determines the use of applied phosphorus by a plant is phosphorus use efficiency (PUE). In general, the phosphorus use efficiency is less as only $30 \%$ of the applied phosphorus is taken by plants in its entire growing season and phosphorus recovery efficiency of applied fertilizers in soil by the crop plant is less than $20 \%$ (Fageria et al., 2011). Intercropping system is one of the best strategies to improve PUE (Hasan et al., 2016).

\section{Materials and Methods}

A field experiment was conducted at the Main Agricultural Research Station, University of Agricultural Sciences, Dharwad, during July 2018. The soil was clay loam, neutral in $\mathrm{p}^{\mathrm{H}}$ (7.34), low in available nitrogen (254.2 $\mathrm{kg} \mathrm{ha}{ }^{-1}$ ), medium in available phosphorus $\left(24.7 \mathrm{~kg} \mathrm{ha}^{-1}\right)$ and high in available potassium $\left(392 \mathrm{~kg} \mathrm{ha}^{-1}\right)$, low in organic carbon $(0.38 \%)$, normal in salt content $\left(0.36 \mathrm{dSm}^{-1}\right)$.

The experiment was laid out in split plot design with three replications and consisted of two fertilizer levels to intercrop as main plots, (50 and $100 \%$ RDF to intercrop), four N:P ratios to pigeonpea as subplots $(1: 2-25: 50 \mathrm{~kg}$ $\mathrm{N}: \mathrm{P}_{2} \mathrm{O}_{5} \mathrm{ha}^{-1}, 1: 2.5-25: 62.5 \mathrm{~kg} \mathrm{~N}: \mathrm{P}_{2} \mathrm{O}_{5} \mathrm{ha}^{-1}$, 1:3-25:75 kg N:P $\mathrm{O}_{5} \mathrm{ha}^{-1}, 1: 3.5-25: 87.5 \mathrm{~kg}$ $\mathrm{N}: \mathrm{P}_{2} \mathrm{O}_{5} \mathrm{ha}^{-1}$ and one absolute control without any fertilizer to both the crops. The pigeonpea and blackgram cultivator used were TS-3R and DBGV-5, with recommended spacing of $120 \times 20 \mathrm{~cm}$ for pigeonpea and $30 \times 10 \mathrm{~cm}$ for blackgram in intercropping ratio of $1: 3$ and were sown on July 142018 simultaneously.

At the time of sowing both the crop seeds were treated with liquid based microbial cultures of Rhizobium and Pseudomonas straita at $4 \mathrm{ml} \mathrm{kg}^{-1}$ of seeds. Nitrogen and phosphorus were supplied in the form of Urea and SSP as per the treatments. Weeding and plant protection measures were undertaken as per the need of the crops.

Blackgram and pigeonpea were harvested during October and January. The observations 
on yield attributes and yield were recorded at harvest. The economics was worked out based on the prevailing market price for the existing year. Agronomic efficiency of phosphorus indicates increase in yield per $\mathrm{kg}$ of phosphorus fertilizer applied. It was calculated by the following formula as suggested by Fageria et al., (2011).

Agronomic efficiency of phosphorus $=\frac{\text { Yield of fertilized crop- } \text { Yield of un-fertilized crop }}{}$

Quantity of fertilizer applied
Data analysis and interpretation was done using Fischer's method of variance technique as described by Gomez and Gomez (1984). The level of significance used in ' $F$ ' test was $\mathrm{P}=0.05$.

\section{Results and Discussion}

There was no significant effect of fertilizer levels to intercrop on pigeonpea (Table 1). Application of different fertilizer levels to intercrop observed significant effect on seed yield of blackgram (Fig. 1).

Table.1 Effect of fertilizer levels to intercrop and NP ratios to pigeonpea on productivity, economics and phosphorus use efficiency of pigeonpea + blackgram intercropping system

\begin{tabular}{|c|c|c|c|c|c|}
\hline \multirow[t]{2}{*}{ Treatments } & \multicolumn{2}{|c|}{$\begin{array}{c}\text { Seed yield } \\
\left(\mathrm{kg} \mathrm{ha}^{-1}\right)\end{array}$} & \multirow{2}{*}{$\begin{array}{c}\text { Pigeonpea } \\
\text { equivalent } \\
\text { yield }\left(\mathrm{kg} \mathrm{ha}^{-1}\right)\end{array}$} & \multirow{2}{*}{$\begin{array}{l}\text { Net } \\
\text { returns } \\
\left(₹ \text { ha }^{-1}\right)\end{array}$} & \multirow{2}{*}{$\begin{array}{c}\text { Agronomic } \\
\text { efficiency of } P \\
\quad\left(\mathrm{~kg} \mathrm{~kg}^{-1}\right)\end{array}$} \\
\hline & Pigeonpea & Blackgram & & & \\
\hline $\mathbf{F}_{1}$ & $1576^{\mathrm{a}}$ & $566^{\mathrm{b}}$ & $2129^{b}$ & $80968^{b}$ & $6.75^{\mathrm{a}}$ \\
\hline $\mathbf{F}_{2}$ & $1676^{\mathrm{a}}$ & $696^{\mathrm{a}}$ & $2363^{a}$ & $93187^{\mathrm{a}}$ & $5.97^{b}$ \\
\hline S.Em. \pm & 36 & 21 & 36 & 1371 & 0.09 \\
\hline $\mathrm{L}_{1}$ & $1367^{b}$ & $588^{\mathrm{a}}$ & $1947^{b}$ & $71086^{b}$ & $4.45^{\mathrm{b}}$ \\
\hline $\mathbf{L}_{2}$ & $1498^{b}$ & $631^{\mathrm{a}}$ & $2120^{\mathrm{b}}$ & $80278^{b}$ & $5.67^{\mathrm{b}}$ \\
\hline $\mathbf{L}_{3}$ & $1780^{\mathrm{a}}$ & $644^{\mathrm{a}}$ & $2416^{\mathrm{a}}$ & $96435^{a}$ & $7.72^{\mathrm{a}}$ \\
\hline $\mathbf{L}_{4}$ & $1847^{\mathrm{a}}$ & $661^{a}$ & $2499^{a}$ & $100509^{a}$ & $7.60^{\mathrm{a}}$ \\
\hline S.Em. \pm & 61 & 23 & 80 & 3963 & 0.60 \\
\hline$F_{1} L_{1}$ & $1327^{\mathrm{c}}$ & $499^{d}$ & $1820^{\mathrm{d}}$ & $64386^{\mathrm{e}}$ & $3.63^{\mathrm{b}}$ \\
\hline$F_{1} L_{2}$ & $1435^{\mathrm{c}}$ & $571^{\mathrm{cd}}$ & $1999^{\text {cd }}$ & $73932^{d e}$ & $5.17^{\mathrm{ab}}$ \\
\hline$F_{1} L_{3}$ & $1716^{\mathrm{ab}}$ & $587^{b-d}$ & $2295^{a-c}$ & $90100^{\mathrm{a}-\mathrm{d}}$ & $7.50^{\mathrm{a}}$ \\
\hline$F_{1} L_{4}$ & $1802^{\mathrm{ab}}$ & $606^{\mathrm{a}-\mathrm{d}}$ & $2400^{\mathrm{ab}}$ & $95452^{a-c}$ & $7.57^{\mathrm{a}}$ \\
\hline$F_{2} L_{1}$ & $1407^{\mathrm{c}}$ & $677^{\mathrm{a}-\mathrm{c}}$ & $2075^{b-d}$ & $77786^{\mathrm{c}-\mathrm{e}}$ & $5.27^{\mathrm{ab}}$ \\
\hline$F_{2} L_{2}$ & $1560^{\mathrm{bc}}$ & $691^{\mathrm{ab}}$ & $2241^{\mathrm{bc}}$ & $86624^{b-d}$ & $6.17^{\mathrm{ab}}$ \\
\hline$F_{2} \mathbf{L}_{3}$ & $1845^{\mathrm{ab}}$ & $702^{\mathrm{a}}$ & $2537^{\mathrm{a}}$ & $102771^{\mathrm{ab}}$ & $7.93^{\mathrm{a}}$ \\
\hline$F_{2} \mathbf{L}_{4}$ & $1891^{\mathrm{a}}$ & $715^{\mathrm{a}}$ & $2597^{\mathrm{a}}$ & $105566^{\mathrm{a}}$ & $7.63^{\mathrm{a}}$ \\
\hline S.Em. \pm & 83 & 35 & 104 & 5044 & 0.85 \\
\hline $\begin{array}{l}\text { Absolute } \\
\text { control }\end{array}$ & 1179 & 373 & 1547 & 53444 & 0.00 \\
\hline S.Em.土 & 88 & 35 & 122 & 5151 & 0.77 \\
\hline C.D. $(P=0.05)$ & 265 & 104 & 367 & 15443 & 2.33 \\
\hline
\end{tabular}


Fig.1 Agronomic efficiency of phosphorus in pigeonpea + blackgram intercropping system

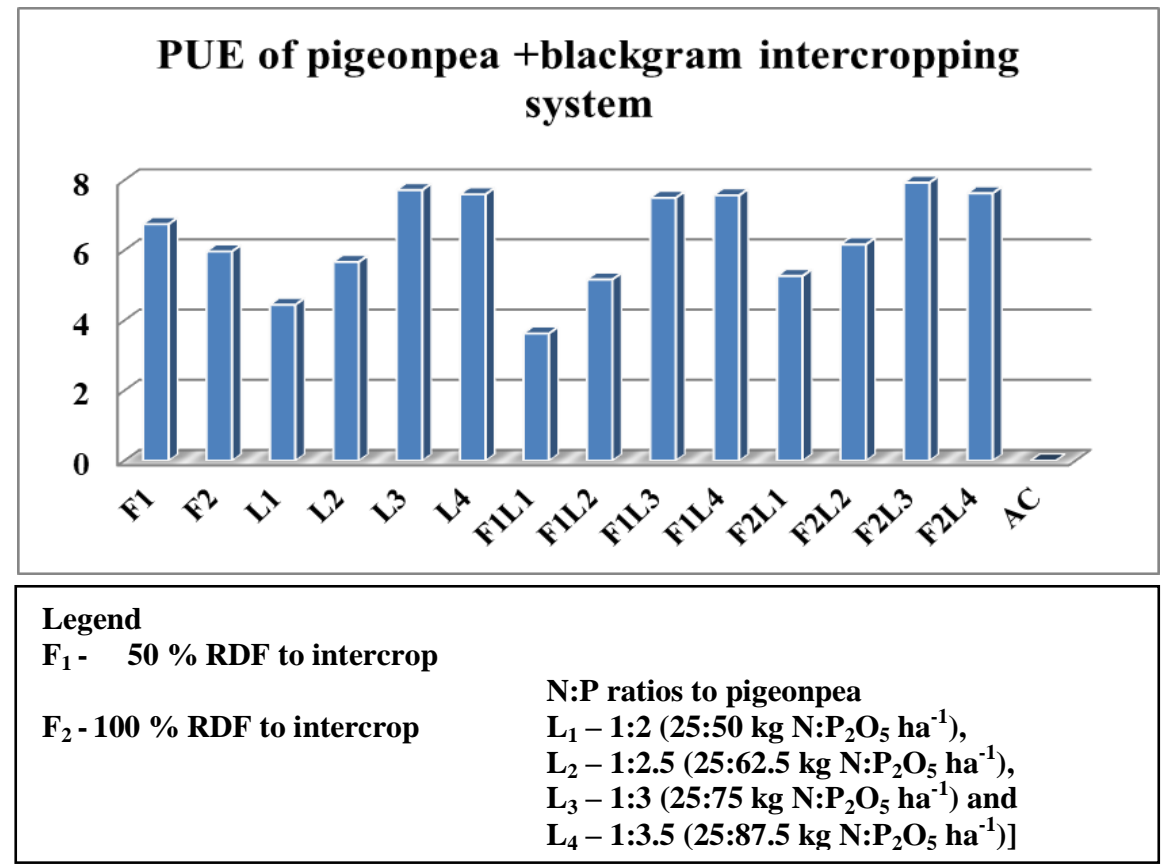

Images of superior treatments and absolute control at harvest stage of pigeonpea
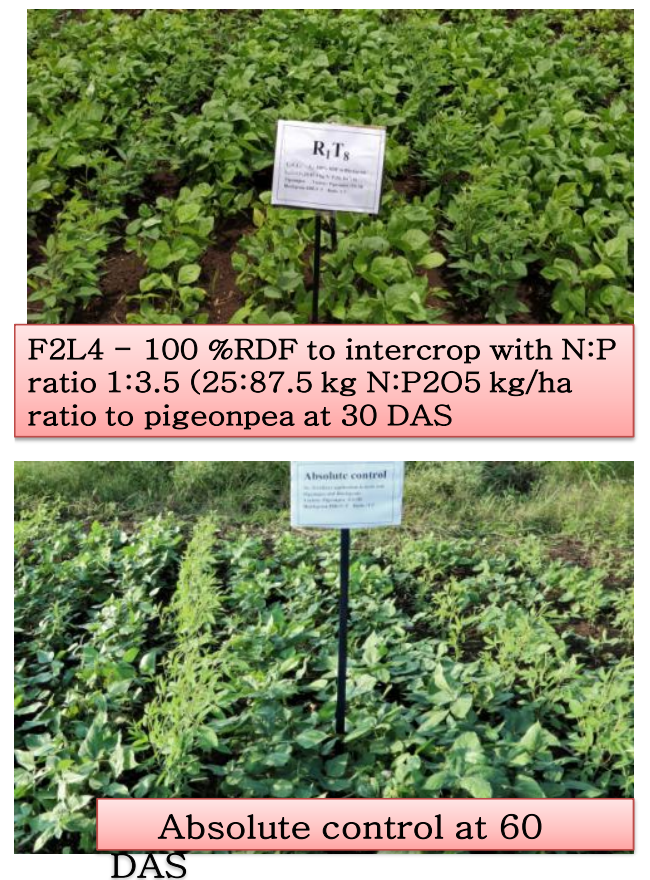

The application of $100 \% \mathrm{RDF}$ to intercrop recorded significantly higher seed yield $(696$ $\mathrm{kg} \mathrm{ha}^{-1}$ ) of blackgram over $50 \% \operatorname{RDF}(566 \mathrm{~kg}$
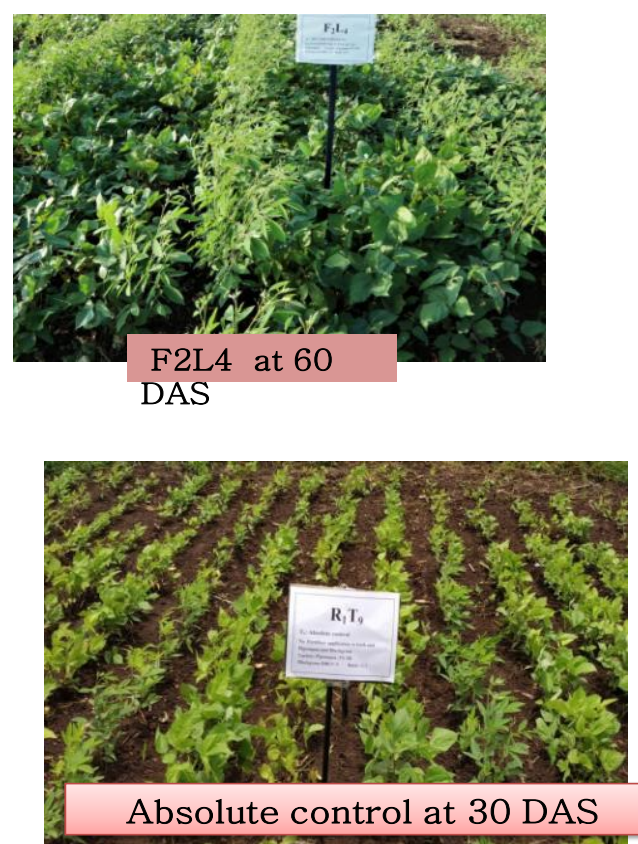

$\left.\mathrm{ha}^{-1}\right)$ and absolute control (373 $\left.\mathrm{kg} \mathrm{ha}^{-1}\right)$. The percent increase in yield compared to absolute control was $86.8 \%$. This was due to optimum 
availability of nutrients $(\mathrm{N}, \mathrm{P}, \mathrm{S}, \mathrm{Ca})$ through urea and SSP for normal growth of intercrop that improved root system, photosynthetic activity, nutrient uptake, dry matter production, reduced flower drop, better pod formation and reduced competition between component crops. Since application method of different fertilizers to component crop was independent that means recommended dose of fertilizer to blackgram and pigeonpea were applied to respective rows of crops, there was no competition for nutrients between the component crops. Similar results were reported by Vishwanatha et al., (2012) in pigeonpea + sunflower.

Among the NP ratios to pigeonpea, 1:3 and 1:3.5 ratios $\left(25: 75,25: 87.5 \mathrm{~kg} \mathrm{~N}: \mathrm{P}_{2} \mathrm{O}_{5}\right.$ ha $\left.^{-1}\right)$ recorded significantly higher seed yield (1780 and $1847 \mathrm{~kg} \mathrm{ha}^{-1}$, respectively) of pigeonpea. These treatments also observed significantly higher PEY (2416 and $2499 \mathrm{~kg} \mathrm{ha}^{-1}$, respectively), net returns ( $₹ 96,435$ and 1,00,509 $\mathrm{ha}^{-1}$, respectively) and PUE (7.72 and $7.60 \mathrm{~kg} \mathrm{~kg}^{-1}$, respectively). This was due to beneficial effect of nitrogen and phosphorus that relatively increased higher root proliferation, more $\mathrm{N}_{2}$ fixation by nodules, photosynthesis and better translocation of photosynthates from source to sink. These results are in conformity with Singh et al., (2017) in pigeonpea. Yield of blackgram recorded was non-significant due to NP ratios to pigeonpea where it influenced the pigeonpea yield significantly (Table 1).

Among the interactions, the $100 \% \mathrm{RDF}$ to intercrop with $\mathrm{NP}$ ratio of $1: 3$ and $1: 3.5$ to pigeonpea recorded significantly higher seed yield (1845, 1891 and 702, $715 \mathrm{~kg} \mathrm{ha}^{-1}$, respectively) of pigeonpea and blackgram. Meanwhile, these treatments also exhibited significantly higher PEY and net returns (2537, $2597 \mathrm{~kg} \mathrm{ha}^{-1}$ and ₹ 1,02,771, 1,05,566 $\mathrm{ha}^{-1}$, respectively) compared to others and absolute control (1547 $\mathrm{kg} \mathrm{ha}^{-1}$ and ₹ 53,444 $\mathrm{ha}^{-1}$, respectively) which remained on par with $50 \% \mathrm{RDF}$ to intercrop with $\mathrm{N}: \mathrm{P}$ ratio of $1: 3$ and 1:3.5 (2295, $2400 \mathrm{~kg} \mathrm{ha}^{-1}$ and $₹$ $90,100,95,452 \mathrm{ha}^{-1}$, respectively) given in Table 1. PUE was recorded significantly higher with 50 and $100 \%$ RDF to intercrop and NP ratio of $1: 3$ and $1: 3.5(7.50,7.57$ and $7.93,7.63 \mathrm{~kg} \mathrm{~kg}^{-1}$, respectively) over absolute control (0.00). This was due to legume effect, an associated blackgram had a positive effect on yield of pigeonpea by adding some nitrogen to soil and during its early stage of crop growth, it suppressed weeds, enhanced moisture availability, reduced evapotranspiration, added organic matter to soil to improve soil physical, chemical and biological properties. Here, higher price of both the crops resulted in higher PEY and net returns. In the system efficiency, crop responded very well for upto $75 \mathrm{~kg}$ phosphorus application and further it starts to decline gradually. This indicated the response of pigeonpea for $\mathrm{P}$ nutrient is relatively high; upto $75 \mathrm{~kg} \mathrm{P}_{2} \mathrm{O}_{5}$ ha $^{-1}$ Ahirwar et al., (2016).

Based on the results of the present investigation it can be concluded that, when main crop (pigeonpea) was given with $\mathrm{N}: \mathrm{P}$ ratio of 1:3, fertilizer dose of intercrop (blackgram) can be reduced to $50 \%$ without compromising the PEY, net returns and PUE in pigeonpea + blackgram intercropping system.

\section{References}

Anonymous, 2018, Area, production and productivity, Ministry of Agriculture and Farmers Welfare, Government of India, Website:http://www.Indiastat.com

Anonymous, 2018a, Area, production and average yield, Directorate of Economics and Statistics, Department of Agriculture and Cooperation, report, New Delhi, p.12. available on the 
website: http://www.agricoop.nic.in.

Ahirwar, R. P., Mishra, U. S., Mitra, N. G. and Sirothia, P., 2016, Effect of phosphorus and biofertilizers on phosphorus use efficiency, biological N-Fixation and yield of pigeonpea (Cajanus cajan L). Int. J. Agric. Envi. and Biotech., 9(6): 1039-1043.

Fageria, N. K., Baligar, V. C. and Jones, C. A., 2011, Growth and mineral nutrition of field crops. CRC Press, pp. 57-67.

Gomez, K. A. and Gomez, A. A., 1984, Statistical Procedure for Agricultural Research. John Willey and Sons, New York, pp. 680.

Hasan, M., Hasan, M., Jaime, A., Silva, T. and Xuexian, L., 2016, Regulation of phosphorus uptake and utilisation: transitioning from current knowledge to practical strategies. Cellular and Molecular Biology Letters., 21:7.

Nagar, R. K., Goud, V. V., Kumar, R. and
Kumar, R., 2015, Effect of incorporation of FYM, pigeonpea stalk, phosphocompost on growth, yield and nutrient uptake in pigeonpea based intercropping system. The Bioscan., 10: 339-343.

Singh, A. K., Singh, R. S., Singh, S. P., Kumawat, N. and Kumar, R., 2017, Productivity, Profitability and Soil Health of Pigeonpea as Influenced by Phosphorus Levels and Bioinoculants under Eastern Uttar Pradesh. Int. J. Curr. Microbiol. App. Sci., 6(6): 17231732.

Vishwanath, S., Anilkumar, S. N., Koppalkar, B. G., Pujari, B. T. and Desai, B. K, 2012, Effect of fertilizer management on economics and yield advantages of pigeonpea and sunflower intercropping system. Int. J. Forestry and Crop Improvement., 3 (2): 76-79.

\section{How to cite this article:}

Deepa Kempagoudra and Ganajaxi Math. 2020. Phosphorus Use Efficiency as Influenced by NP Ratios to Pigeonpea and Fertilizer Levels to Intercrop in Pigeonpea + Blackgram System. Int.J.Curr.Microbiol.App.Sci. 9(11): 550-555. doi: https://doi.org/10.20546/ijcmas.2020.911.067 